
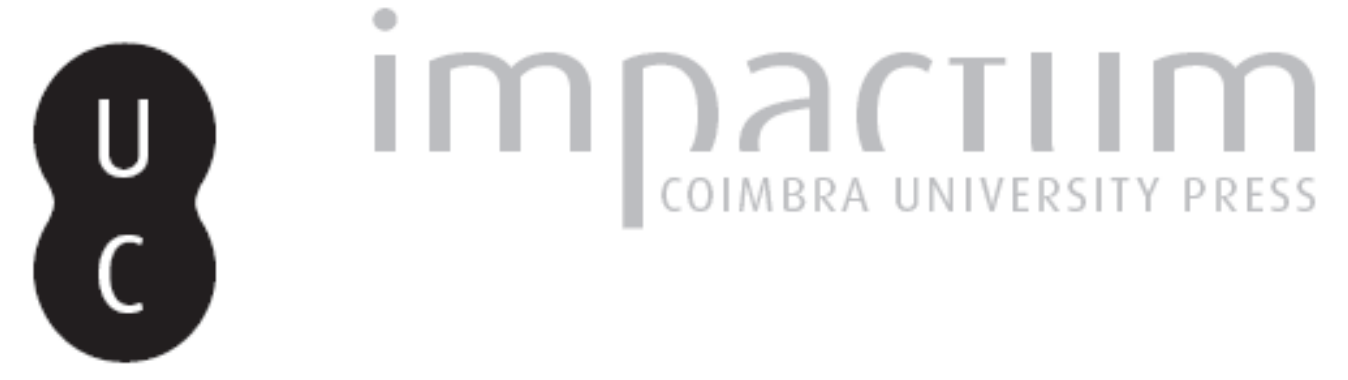

\title{
A intersubjetividade a partir das relações espaciais em Jean-Paul Sartre
}

Autor(es): $\quad$ Corbella, Lucrecia

Publicado por: Imprensa da Universidade de Coimbra

URL persistente:

URI:http://hdl.handle.net/10316.2/42829

DOI:

DOI:http://dx.doi.org/10.14195/0872-0851_48_6

Accessed : $\quad$ 26-Apr-2023 12:33:42

A navegação consulta e descarregamento dos títulos inseridos nas Bibliotecas Digitais UC Digitalis, UC Pombalina e UC Impactum, pressupõem a aceitação plena e sem reservas dos Termos e Condições de Uso destas Bibliotecas Digitais, disponíveis em https://digitalis.uc.pt/pt-pt/termos.

Conforme exposto nos referidos Termos e Condições de Uso, o descarregamento de títulos de acesso restrito requer uma licença válida de autorização devendo o utilizador aceder ao(s) documento(s) a partir de um endereço de IP da instituição detentora da supramencionada licença.

Ao utilizador é apenas permitido o descarregamento para uso pessoal, pelo que o emprego do(s) título(s) descarregado(s) para outro fim, designadamente comercial, carece de autorização do respetivo autor ou editor da obra.

Na medida em que todas as obras da UC Digitalis se encontram protegidas pelo Código do Direito de Autor e Direitos Conexos e demais legislação aplicável, toda a cópia, parcial ou total, deste documento, nos casos em que é legalmente admitida, deverá conter ou fazer-se acompanhar por este aviso.

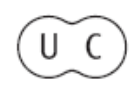




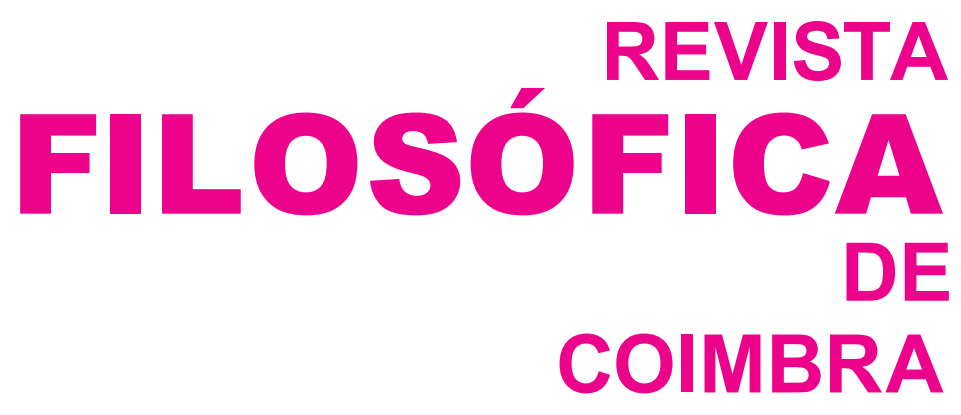

vol. 24 - número 48 - outubro 2015

vol. 24 - número 48 - outubro 2015

Fundação Eng. António de Almeida

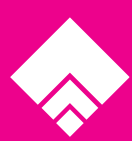




\title{
A INTERSUBJETIVIDADE A PARTIR DAS RELAÇÕES ESPACIAIS EM JEAN-PAUL SARTRE
}

\author{
LUCRECIA CORBELLA ${ }^{1}$
}

Resumo: Este artigo visa compreender a intersubjetividade a partir da fenomenologia da espacialidade que Sartre desenvolve de forma algo esparsa ao longo de sua obra. Desde logo, com implicações para a própria constituição do ego. É, com efeito, a partir das proximidades e distanciamentos com os objetos do mundo e com os outros que neles descobrimos que os limites do nosso corpo adquirem uma dimensão própria e o Ego se reconhece num mundo onde é encontrável. Ego, intersubjetividade e mundo não dispensam, pois, uma referência à espacialização como materialidade por que se particulariza de modo concreto a alteridade.

Palavras-chave: intersubjetividade, espacialidade fenomenológica, Jean-Paul Sartre.

Abstract: This article aims at understanding inter-subjectivity from the point of view of the phenomenology of spatiality developed throughout Sartre's work somehow sparsely. Implicating primarily the constitution of the Ego. From proximities and distances to the objects of the world and to others the limits of our body acquire their own dimension and the Ego is recognized in a world where it can be found. Ego, inter-subjectivity and world cannot be disconnected from a reference to spatialization as materiality in which otherness is particularized in a concrete way.

Keywords: inter-subjectivity, spatiality phenomenological, Jean-Paul Sartre.

${ }^{1}$ Pós-Doutoranda do Programa de Pós-Graduação em Filosofia da Universidade Federal de São Carlos/ UFSCar (Brasil)/ Bolsa FAPESP. Doutora em Psicologia Social pela Universidade do Estado do Rio de Janeiro/UERJ (Brasil) /Bolsa CAPES, com estágio doutoral no exterior/PDSE/ Bolsa CAPES em Filosofia no Instituto de Filosofia Prática/ IFP na Universidade da Beira Interior/UBI/ Portugal; email: lucorbella@ig.com.br 


\section{Introdução}

A questão da intersubjetividade e de sua relação íntima com o espaço é trabalhada de forma muito rigorosa pelo filósofo Jean-Paul Sartre em seu tratado filosófico L'être et le néant, Essai d'ontologie phénoménologique ${ }^{2}$. A psicologia realista e positivista do século XIX partia do pressuposto que a existência do outro era uma certeza. Uma vez que o outro é um dado certo, o que se investigava, por analogia ao conhecimento que eu possuo de mim mesmo, eram quais as formas de se conhecer este outro. Mas para Sartre o que o realismo da época constrói como certeza, é algo somente da ordem do provável, pois através deste método é impossível definir se o que eu vejo é um homem, um animal ou uma máquina. Tanto o realismo quanto o idealismo definiram o outro como uma negação, ou seja, o outro é aquilo que não sou eu. Há uma separação espacial entre meu eu e o outro que é um nada; este nada separa o que eu sou do que eu não sou; há um "nada dado" ${ }^{3}$ que separa a minha consciência da consciência do outro e também meu corpo do corpo do outro. É por esta razão que, no entender de Sartre, tanto no realismo como no idealismo "[...] a negação constituinte é uma negação de exterioridade." Sartre considera que a filosofia dos séculos XIX e XX realiza a tentativa de resolver a questão do solipsismo através de teorias que coloquem no interior da consciência "[...] uma ligação fundamental e transcendente ao outro que seria constitutiva de cada consciência no seu próprio surgimento." ${ }^{\text {. Pois se }}$ a relação com o outro continua a ser pensada a partir de duas estruturas distintas, o eu e o outro, separadas na origem, é impossível, para Sartre, refutar o solipsismo:

Parece que a filosofia dos séculos XIX e XX compreendeu que não se pode escapar ao solipsismo se consideramos primeiramente eu-mesmo e o outro sob o aspecto de duas substâncias separadas: toda união dessas substâncias, em efeito, deve ser mantida como impossível. É por isto que o exame das teorias modernas nos revela um esforço para apreender no âmago mesmo das consciências uma ligação fundamental e transcendente ao outro que seria constitutiva de cada consciência no seu próprio surgimento. ${ }^{6}$

Após considerar as teorias dos filósofos Edmund Husserl, Georg Wilhelm Friedrich Hegel e Martin Heidegger a respeito do entendimento da nossa

2 Jean-Paul Sartre, L'être et le néant. Essai d'ontologie phénoménologique (Paris: Gallimard, 2007).

3 Sartre, L'être, 269.

4 Sartre, L'être, 269.

5 Sartre, L'être, 271.

6 Sartre, L'être, 271. 
relação com o outro, Sartre afirma que há um salto qualitativo na teoria de Hegel em relação à teoria de Husserl, pois este último coloca a questão da aparição do outro como "uma condição necessária de meu ser para "eu-mesmo.(moi-même)" ". Embora este salto seja significativo, o filósofo francês argumenta que tanto Husserl quanto Hegel se baseiam em uma relação de interioridade que ainda é pensada em termos de conhecimento. A única forma de escapar ao solipsismo é, no lugar de pensar uma relação de conhecimento a conhecimento, afirmar uma relação de ser a ser. Por outro lado, mesmo o conceito de être-avec, de Heidegger, no qual haveria uma coexistência de consciências, não escapa ao idealismo, pois "[...] nós encontramos o outro, não o constituímos." "Sartre pensa que estes três filósofos se aproximam na tentativa de refutar o solipsismo, pois todas as suas teorias caem no idealismo no qual o lugar do outro é entendido apenas como uma probabilidade. É com o intuito de defender uma "ligação fundamental e transcendente com o outro"9 que Sartre escreverá o texto Le regard.

\section{Os elos espaciais e a intersubjetividade}

A objetividade é uma das formas pelas quais o outro é uma presença para mim; esta presença do outro se dá na realidade cotidiana. O filósofo francês questionará se na realidade cotidiana se encontraria esta relação fundamental com o outro. Sartre responderá que "[...] minha ligação fundamental com o outro-sujeito deve poder ser reconduzida à minha possibilidade permanente de ser visto pelo outro." $10 \mathrm{O}$ olhar do outro me delimita, me fixa em determinada situação, em um dos meus infinitos possíveis e me faz ver que eu não estou no centro do mundo a controlar minha existência. O que emerge desta relação de "ser-visto-pelo-outro"11 é um sentimento de ambiguidade que traz à tona, em primeiro lugar, minha condição de liberdade e, ao mesmo tempo, os limites desta liberdade em situação. É por esta razão que Sartre concebe que "[...] o olhar do outro me confere a espacialidade. Captar-se como visto é captar-se como espacializador-espacializado."12 Desta forma, é a partir do outro, do olhar do outro que tenho consciência da minha espacialidade e, além disso, da minha temporalidade. Há uma presença simultânea de dois olhares, o do outro que me vê e, ao mesmo tempo, o meu olhar enxergando

\footnotetext{
7 Sartre, L'être, 277.

${ }^{8}$ Sartre, L'être, 289.

9 Sartre, L'être, 271.

10 Sartre, L'être, 296.

11 Sartre, L'être, 296.

12 Sartre, L'être, 306.
} 
o outro que me olha, que instaura uma temporalidade que conecta duas presenças no tempo e no espaço; é através do olhar do outro que inauguro estas duas dimensões em meu ser: espacialidade e temporalidade. Além de instaurar estas duas dimensões em meu eu, o olhar do outro provoca em mim sentimentos específicos que são as formas pelas quais eu lido com o olhar do outro:

Vergonha, medo e orgulho são, portanto, minhas reações originais, as diversas maneiras pelas quais reconheço o outro como sujeito fora de alcance, e encerram uma compreensão de minha ipseidade que pode e deve servir-me de motivação para constituir o outro como objeto. ${ }^{13}$

No caso da vergonha, por exemplo, é possível entender que o outro que me olha me fixa em determinada ação numa situação específica, me coloca no meio mundo, sem que eu tenha controle sobre este mundo e este olhar do outro delimita minhas possibilidades. No entender de Sartre "A vergonha [...] é o sentimento original de ter meu ser fora, comprometido com um outro ser e, como tal, sem defesa alguma." ${ }^{14}$.Se não estivéssemos em uma relação, o sentimento da vergonha não apareceria, pois a vergonha coloca em evidência o fato de que meu ser se constitui a partir do outro, a partir do seu olhar. É por esta razão que Sartre pensa este sentimento a partir de um tripé relacional que a sustenta "[...] a vergonha é a apreensão unitária de três dimensões: "Eu tenho vergonha de mim frente ao outro." Se uma destas dimensões desaparece, a vergonha desaparece também." 15 No instante no qual percebo que o outro me olha, eu passo a ser objeto deste olhar do outro que instaura uma relação espacial e afetiva entre nós dois. Eu me torno aquele que faz determinada ação em determinado meio e com certas distâncias entre os objetos e as pessoas que estão ao meu redor. Sinto vergonha do olhar do outro, pois ele desnuda o meu ser finito e limitado; o olhar do outro denuncia a minha liberdade de escolha em ser de uma determinada maneira e, ao fazê-lo, nega todas as demais formas exuberantes que eu poderia ter sido e não sou. Através do olhar do outro eu me reconheço como um ser pequeno e aprisionado ao invés de ser um ser alado ou possuir superpoderes. É este olhar que me confere a minha humanidade singela e mortal, simples e concreta, falha e repleta de erros; este é o sentido de se sentir nu diante do outro. A vergonha da nudez diante do olhar outro revela a fragilidade da existência que, no entender do filósofo português André Barata, significa "[...] a fragilidade de se descobrir num mundo, aí, vulnerável, não fisicamente vulnerável, mas ontologicamen-

\footnotetext{
13 Sartre, L'être, 330.

14 Sartre, L'être, 328.

15 Sartre, L'être, 329.
} 
te vulnerável."16 . A personagem Ercília, da peça de teatro Vestir os Nus, do dramaturgo italiano Luigi Pirandello, coloca em cena a angústia de uma mulher que é descoberta pelo olhar do outro como alguém que tomou decisões erradas e que acabou por tornar sua vida vazia de sentido. As "estórias" que Ercília inventava a respeito da sua vida preenchiam seu vazio existencial e também o vazio existencial do jornalista que se propunha a publicar sua "história" de vida. Ercília, ao construir histórias para a sua vida, estava se vestindo e para o filósofo Sartre "[...] Vestir-se é dissimular sua objetividade, reclamar o direito de ver sem ser visto, ou seja, de ser puro sujeito."17

É a partir do olhar do outro que me objetifica que eu tomo consciência de mim mesmo; eu sou um objeto para o outro, mas o outro jamais será um objeto para mim. Sartre considera que "[...] a vergonha (...) é vergonha de $s i$, ela é reconhecimento de que eu sou este objeto que o outro olha e julga." 18 É como se eu somente pudesse saber quem eu sou a partir deste olhar do outro; no mesmo instante que o outro me olha, se inaugura o meu ser. Sartre define o olhar do outro da seguinte maneira:

Transcendência onipresente e inapreensível, posta sobre mim sem intermediário enquanto eu sou meu ser-não-revelado, e separada de mim pelo infinito do ser, enquanto que eu sou tomado por este olhar no meio de um mundo completo com suas distâncias e seus utensílios. ${ }^{19}$

Uma vez mais é preciso ressaltar que esta não é uma relação de conhecimento a conhecimento e sim de ser a ser na qual eu instauro os contornos do meu ser a partir desta liberdade do outro da qual eu não tenho controle: "[...] o outro, pelo qual este eu me advém, não é nem conhecimento nem categoria, mas o fato da presença de uma liberdade étrangère." ${ }^{20}$ Esta liberdade estrangeira, que é totalmente desconhecida para mim, ao mesmo tempo em que me arrebata e me deixa totalmente sem controle da situação, me especializa e me temporaliza, desenhando os contornos do meu ser, ou seja, o meu corpo. O meu corpo será definido através da presença e ausência de distancias e proximidades entre as pessoas que se encontram ao meu redor e também entre os utensílios que estão localizados no meu horizonte de possibilidades. A ausência possui uma relação íntima com a presença já que só é possível falar da ausência de algo que foi um dia presença. Sartre considera que a

16 André Barata, "Vida temporal comum: o caráter temporal da intersubjetividade afetiva", in Tempo e Subjetividades, perspectivas plurais, org. Ariane Ewald et al. (Rio de Janeiro: 7Letras:Pequeno Gesto, 2013), 120.

17 Sartre, L'être, 328.

18 Sartre, L'être, 300.

19 Sartre, L'être, 309.

20 Sartre, L'être, 314. 
ausência "[...] é uma ligação entre realidades-humanas, não entre a realidade-humana e o mundo." 21 E ainda complementa "[...] É em relação a todo homem vivo que toda realidade-humana é presente ou ausente sobre o fundo de presença original." 22 Então, sob este fundo de presença original, eu percebo e vivencio presenças e ausências que delimitarão meu espaço vital e os contornos do meu corpo. Presença ou ausência sempre diz respeito a uma relação do meu eu com as distâncias que estabeleço entre eu e o outro, que justamente delimitarão quem sou eu e quem é o outro: “[...] Eu somente posso manter o outro à distância aceitando um limite à minha subjetividade."23 Este limite espacial somente é possível de ser feito a partir de minha condição de liberdade que me impele a escolher um caminho ou outro em cada situação. Essa escolha é irreversível; pois ao transformar meu espaço vital, transforma-se minha vida e das pessoas que se encontram ao meu redor sem que exista a possibilidade da tecla pause ou delete.

A concepção idealista de espaço que o considera como "uma multiplicidade de relações recíprocas" 24 é ultrapassada, no entender de Sartre, pois esta multiplicidade somente existe, de fato, na abstração. $\mathrm{O}$ que a ciência moderna trará de novo será a incorporação do homem, do observador neste mundo que era pensado como objetividade absoluta que, na verdade, excluía os sujeitos. O filósofo francês considera que o mundo não é uma abstração, ele é um fato concreto que somente existe para a realidade humana; o mundo passa a existir no momento no qual se estabelece uma relação relativa a este mundo. É a relação específica, situada, engajada, homem-mundo que inaugura uma existência e um mundo; antes dessa relação, não existe homem nem mundo. $\mathrm{O}$ mundo aparece para mim com uma certa organização e esta organização que eu enxergo no mundo nada mais é do que a constituição do meu corpo em relação com o mundo.

A relação que um ser humano estabelece com o mundo se concretiza a partir da relação que ele estabelece com as demais pessoas e com os objetos que estão ao seu redor. Tanto as pessoas quanto os objetos não aparecem à percepção de forma isolada e sim com uma teia de significações na qual objetos e pessoas encontram-se enredados. Mas é preciso entender que a posição que cada qual ocupa na teia é constituída de sentido: “[...] Os objetos se revelam para nós no âmago de um complexo de utensílios no qual eles ocupam um lugar determinado. Este lugar não é definido por puras coordenadas espaciais, mas pela relação com eixos de referências práticas." 25

\footnotetext{
21 Sartre, L'être, 318.

22 Sartre, L'être, 319.

23 Sartre, L'être, 325.

${ }^{24}$ Sartre, L'être, 346.

25 Sartre, L'être, 361.
} 
Estas referências práticas dizem respeito às ações de proximidade e de afastamento que estabeleço entre meu ser e os objetos e entre meu ser e as pessoas, ou seja, ao espaço que constituo como sendo o "meu mundo". No entender de Sartre:

O espaço original que se descobre para mim é o espaço hodológico; ele é sulcado de caminhos e de rotas, ele é instrumental e ele é o local das ferramentas. Desta forma o mundo, desde o surgimento de meu para-si, se revela como indicação de atos a fazer, estes atos reenviam a outros atos, estes a outros e assim por diante. ${ }^{26}$

É por esta razão que Sartre escreverá que, neste caso, "percepção e ação são indiscerníveis" 27 , pois percebo o mundo a partir da intenção das ações que realizarei, no futuro, neste mundo. Desta forma é possível compreender que o mundo que constituo como "meu mundo" está em uma relação íntima com o prolongamento das minhas ações neste mundo "[...] o mundo, como correlativo das possibilidades que eu sou, aparece, desde meu surgimento, como o enorme esboço de todas as minhas ações possíveis." ${ }^{28}$ Este esboço no espaço hodológico é feito no presente, mas a sua direção aponta para o futuro, pois cada ação levará a outra ação que ainda não existe, que será engendrada a posteriori: "[...] cada remissão (renvoi) significante aos outros objetos engaja o futuro" 29 .

\section{As emoções a partir de uma teoria fenomenológica}

É com o intuito de tentar compreender as noções sartreanas de espacialidade tais como lugar, espaço hodológico e coordenadas espaciais, que deixar-se-á por um momento de lado o L'être et le néant e se versará, ainda que de forma sucinta, sobre Esquisse d'une théorie des émotions. Este ensaio, de 1939, anterior ao L'être et le néant, de 1943, foi escrito por Sartre no intuito de formular uma teoria fenomenológica das emoções opondo-se de forma radical à formulação da teoria psicológica da época. No entender de Sartre, a psicologia que ganhava força como campo de estudo e prática clínica até o início do século XX na Europa ocidental seguia o modelo das ciências positivistas. A psicologia do século XIX e início do século XX, calcada no modelo das ciências biológicas, se baseava em experiências, ou seja, em fatos ditos cientificamente comprováveis que ela generalizava para todo e

\footnotetext{
26 Sartre, L'être, 361.

27 Sartre, L'être, 361.

28 Sartre, L'être, 362.

29 Sartre, L'être, 361.
} 
qualquer homem. Um homem, para a psicologia, era definido através de uma reunião de fatos comprováveis, argumento que Sartre considerava muito frágil enquanto pressuposto teórico: “[...] Os psicólogos não se dão conta, com efeito, de que é tão impossível atingir a essência amontoando os acidentes quanto chegar à unidade acrescentando indefinidamente algarismos à direita de 0,99." 30 Partindo da certeza de que uma reunião de experiências que se repetiam e que poderiam ser encontradas em todos os homens, a psicologia da época acreditava que seria possível falar em "realidade humana". Era preciso, no entender do filósofo francês, outro arcabouço teórico para que a psicologia pudesse explicar a complexidade do ser humano: "Foi pela reação contra as insuficiências da psicologia e do psicologismo que se constitui , há cerca de trinta anos, uma disciplina nova, a fenomenologia." 31 Para Sartre "[...] o princípio da fenomenologia é ir "às coisas mesmas", e a base de seu método é a intuição eidética" 32 . A psicologia, para compreender o homem em situação, precisa, antes de tudo, tomar a atitude de "colocar do mundo entre parêntesis" 33 . Colocar o mundo entre parêntesis significa suspender o juízo de valor sobre as coisas, ou seja, não preconceber as coisas através de algo externo a elas mesmas. Podemos também chamar este processo de "desnaturalização" do olhar; é ser capaz de ter um olhar estrangeiro sobre as coisas, como se as olhássemos por primeira vez. Através da perspectiva da fenomenologia, se estuda um fenômeno como se, a princípio, não soubéssemos nada a respeito dele. Perguntar-se-á ao fenômeno (e não ao fato, Sartre frisa esta distinção com todas as palavras) sobre ele mesmo, sem nenhum julgamento prévio a partir de seu exterior. O fenômeno, em sua aparência, dirá sobre ele próprio de forma completa, sem deixar nada oculto da qual não se possa compreender. O heterônimo de Fernando Pessoa, Alberto Caeiro, também pensa que as coisas, por elas próprias, já detém toda a sua significação. Apesar de ter nascido em 1889 em Lisboa, Caeiro era um homem com pouca instrução que passou a maior parte de sua vida no campo. Seus pensamentos e seus poemas são oriundos do contato com a natureza que ele vivenciou numa quinta no Ribatejo. Local de uma natureza exuberante, o Ribatejo, banhado pelo Rio Tejo, é um local muito rico e fértil, propicio para o cultivo de plantações e para a criação de rebanhos. Caeiro era um homem simples que acreditava que o mundo é tal qual ele se apresenta; para o poeta, não há nenhuma significação oculta em outro lugar que não o lugar das coisas mesmas:

\footnotetext{
30 Jean-Paul Sartre, Esquisse d'une théorie des émotions (Paris: Hermann, 1960), 9-10.

31 Sartre, Esquisse, 12.

32 Sartre, Esquisse, 12.

33 Sartre, Esquisse, 13.
} 
O que nós vemos das coisas são as coisas.

Porque veríamos nós uma coisa se houvesse outra?

Porque ver e ouvir seria iludirmo-nos

Se ver e ouvir são ver e ouvir?

O essencial é saber ver,

Saber ver sem estar a pensar,

Saber ver quando se vê,

E nem pensar quando se vê,

Nem ver quando se pensa. ${ }^{34}$

A fenomenologia considera que todo e qualquer fenômeno é significativo sem que haja uma hierarquia que considere alguns fenômenos mais relevantes do que outros. Um fenômeno, da mesma forma que é considerado significativo, não pode ser compreendido de forma isolada, pois um fenômeno sempre remeterá a outro fenômeno que se encontra ligado a este em determinada situação. A significação de um fenômeno só poderá ser compreendida na relação com outros fenômenos que se organizam de uma maneira singular e própria.

Há uma forma própria de organização da realidade humana que é a emoção. Sartre argumenta que, para entendê-la, ele se voltará para os "processos da própria emoção" 35 no lugar de tentar explicá-la através destas leis gerais nas quais a psicologia se baseava. No livro Esquisse d'une théorie des émotions, Sartre destaca que, apesar das teorias clássicas da emoção do psicólogo estadunidense William James e do psicólogo francês Pierre-Marie-Félix Janet se aproximarem muito no sentido de explicar a emoção fundamentalmente através de processos fisiológicos, a teoria de Janet dá um passo à frente. A partir da formulação da "conduta do fracasso" (conduite d'échec), Janet é o primeiro psicólogo a conceber uma teoria psicológica na qual a emoção é concebida como "[...] um sistema organizado de meios que visam a um fim. E esse sistema é convocado para mascarar, substituir, rechaçar uma conduta que não se pode ou não se quer assumir." ${ }^{36}$ Apesar de considerar que esta teoria realizou avanços ao conceber a emoção como um conjunto de condutas organizadas ao invés de uma resposta fisiológica como W. James a concebia, Sartre considera a teoria de Janet frágil por não tecer uma relação íntima entre emoção e consciência.

A teoria psicanalítica, assim como as teorias psicológicas clássicas, no entender de Sartre, não explica de forma significativa a emoção por reduzila a um mecanismo ao invés de entendê-la como um sistema complexo de

${ }^{34}$ Fernando Pessoa, Obra poética II. Poemas de Alberto Caeiro (Porto Alegre, RS: L\&PM, 2012), 63.

35 Sartre, Esquisse, 12.

36 Sartre, Esquisse, 27. 
funcionamento da consciência. Para a psicanálise, a emoção se reduz a uma série de manifestações de origem inconsciente que tentamos, em vão, controlar.

Como Sartre não se satisfaz com as explicações das teorias clássicas da psicologia nem com a teoria psicanalítica da época, o filósofo francês analisa a emoção a partir de uma teoria fenomenológica. Há neste livro, em princípio, duas considerações muito relevantes sobre a emoção que modificam completamente a forma de compreendê-la. A primeira delas diz respeito à relação entre a emoção e consciência: "[...] A consciência emocional é primeiramente irrefletida e, nesse plano, ela só pode ser consciência dela mesma no modo não-posicional. A consciência emocional é, em primeiro lugar, consciência do mundo." ${ }^{37}$ Para que se possa compreender melhor estas noções apresentadas, Sartre nos brinda com o exemplo do ato de escrever. No momento no qual escrevo, não tenho consciência deste ato nem das palavras que escolho utilizar para escrever meu texto. Isto não quer dizer que o ato de escrever seja um ato inconsciente, nem que seja um ato motivado pela força do hábito. É um ato que envolve um saber e um saber-fazer conscientes, mas que durante o fazer, não há reflexão sobre este ato. Este é um ato da consciência espontânea irrefletida consciente que não tem consciência dele próprio, somente é consciente dele mesmo não-teticamente. É por esta razão que Sartre concebe que a "conduta irrefletida" 38 faz parte de uma "certa camada existencial no mundo" 39 que está relacionada com a posição que, a cada momento, se traça no mundo. É possível, a partir da conduta irrefletida, fazer uma operação de segundo grau, que é refletir sobre esta conduta irrefletida, mas isto não significa que eu me afaste desta camada existencial do mundo que é irrefletida. Mesmo quando se reflete sobre o irrefletido, o plano do irrefletido continua a existir e eu continuo a agir de forma irrefletida, mesmo quando reflito sobre a minha ação.

A segunda afirmação relevante do livro Esquisse d'une théorie des émotions diz respeito a uma compreensão da emoção como uma forma de se posicionar no mundo: "[...] o sujeito emocionado e o objeto emocionante estão unidos numa síntese indissolúvel. A emoção é uma certa maneira de apreender o mundo." 40 Para que se possa compreender a abrangência desta afirmação sobre a emoção, Sartre coloca em discussão o termo "mapa "hodológico"" 41 , de autoria do psicólogo alemão Kurt Lewin. Este mapa diz respeito a uma série de rotas ou caminhos que vão sendo escolhidos com

\footnotetext{
37 Sartre, Esquisse, 38-39.

38 Sartre, Esquisse, 40.

39 Sartre, Esquisse, 42.

${ }^{40}$ Sartre, Esquisse, 39.

${ }^{41}$ Sartre, Esquisse, 42.
} 
o intuito de se atingir determinado fim. Aquilo que se quer alcançar é da ordem do sonho, desejo ou necessidade: "[...] os objetos "a realizar" aparecem como devendo ser realizados por certos caminhos. Os próprios meios aparecem como potencialidades que reclamam a existência." 42 Como hodos em grego significa caminho, isto quer dizer que o mapa hodológico já indica uma rota a ser seguida, isto é, ele traduz uma organização espacial de meus arredores a partir de meus desejos e de minhas ações. O que salta aos olhos na teoria sartreana da emoção é o entendimento de que os próprios objetos, desejos, necessidades "reclamam a existência", ou seja, solicitam para que se faça a passagem da intenção à ação, tornando-os concretos. Voltando ao ato de escrever, Sartre dirá que "[...] as palavras que escrevo são exigências. (...) Elas aparecem como potencialidades que devem ser realizadas." 43 Assim como as palavras pedem para ser realizadas em um romance, as personagens pirandellianas de Seis Personagens à Procura de Autor ${ }^{44}$ pedem para se tornar realidade no teatro. Nesta peça de Luigi Pirandello, seis personagens que haviam sido descartadas por um autor, aparecem, em um teatro no qual atores ensaiavam uma peça, reclamando sua existência. As personagens afirmam que já existem e que suas histórias de vida precisam ser encenadas, caso contrário, elas morrerão em folhas de papel que o autor abandonou em uma gaveta. Assim como as palavras do romance que Sartre escreve são exigências, as personagens do dramaturgo italiano defendem com unhas e dentes a urgência de se tornarem reais. Da mesma maneira que as palavras pedem para ser realizadas em um romance, os gestos pedem para ser realizados no teatro, pois será através deles que uma personagem se torna real. Entende-se o gesto no teatro como toda e qualquer ação teatral que se esboça a partir de um texto, que é trabalhada e lapidada através de uma encenação e uma direção que tornam concreta esta ação que estava no texto enquanto intenção. É possível, a partir desta perspectiva, entender a imobilidade e o silêncio também como gestos teatrais intencionais.

Neste mapa hodológico estaria presente a inscrição de esboços de caminhos que levariam a atingir certos objetivos, desejos, necessidades, sonhos. $\mathrm{O}$ ato de caminhar por estes esboços de rotas concretiza, a cada momento, uma rota ao invés de outra que poderia ser tomada e faz com que o objeto desejado se torne realidade. Mas o fato de ter escolhido um determinado caminho para alcançar certo objeto não é uma garantia si ne qua non de que o objeto estará lá no fim da travessia. Muitas vezes a Deusa Fortuna nos brinda com moinhos de vento no lugar de gigantes ameaçadores e vice-versa.

42 Sartre, Esquisse, 42.

43 Sartre, Esquisse, 41.

${ }^{44}$ Luigi Pirandello, Seis Personagens à Procura de Autor. Para Cada Um Sua Verdade. Esta Noite Improvisa-se (Lisboa: Artistas Unidos/Livros Cotovia, 2009). 
Não é certo que Cavallero de la Triste Figura consiga alcançar sua Dulcinea del Toboso, pois há imensos percalços na travessia, ou como diria o poeta Carlos Drummond de Andrade, pedras no caminho. Mas assim como o poeta Mário Quintana, em seu brilhante Poeminho do contra realiza a metamorfose da pedra que atravanca o caminho em um voo da liberdade, a emoção, da mesma forma, realiza a metamorfose do mundo ameaçador em um mundo possível de se viver. No entender de Sartre, a emoção:

[...] É uma transformação do mundo. Quando os caminhos traçados se tornam muito difíceis ou quando não vemos caminho algum, não podemos permanecer num mundo tão urgente e tão difícil. Todas as vias estão barradas, no entanto é preciso agir. Então nós tentamos mudar o mundo, isto é, vive-lo como se as relações das coisas com suas potencialidades não estivessem reguladas por processos deterministas, mas pela magia. Entendamos bem que não se trata de um jogo: estamos acuados e nos lançamos nessa nova atitude com toda a força de que dispomos. ${ }^{45}$

$\mathrm{Na}$ emoção, o corpo, por um ato de crença, passa a estabelecer outras relações com o mundo como se este "fosse" outro, mas o que ocorre de fato é que o mundo "se torna" outro frente aos olhos de uma pessoa emocionada. A emoção é um ato consciente irrefletido que transforma, de uma só vez, o ser humano e o mundo, através de novas relações entre eles tornando factível uma existência em um mundo novo, doravante com caminhos possíveis. Sartre, ao se referir à emoção, coloca em cena a releitura de La Fontaine sobre a Fábula A raposa e as uvas de Esopo. A raposa, ao passar por uma floresta, vê um cacho de uvas maduras que ela tem interesse em apanhar para comê-las. Porém, após inúmeras tentativas fracassadas de alcançar as uvas, a raposa se cansa e desiste do seu desejo. Ao decidir ir embora, a raposa se convence de que as uvas maduras que não estavam ao seu alcance, na verdade, eram uvas verdes, portanto, impróprias para serem comidas.

$\mathrm{Na}$ cena contemporânea, esta questão sartreana da emoção enquanto transformação de mundo é trabalhada de forma contundente pelo diretor de cinema espanhol Pedro Almodóvar. No filme Todo sobre mi madre ${ }^{46}$, de 1999, há uma personagem que afirma que sua missão na vida sempre foi a de agradar aos outros. A personagem Agrado argumenta que gastou uma fortuna com os litros de silicone que aplicou e com as inúmeras cirurgias plásticas realizadas em seu corpo em nome de buscar alcançar o mais próximo possível o que se deseja ser na vida. Em um filme mais recente, Los amantes pasajeros $^{47}$, de 2013, a personagem Norma, depois de perceber que não faria

\footnotetext{
45 Sartre, Esquisse, 43.

46 Pedro Almodóvar, Todo sobre mi madre (Espanha/França: El Deseo, 1999).

47 Pedro Almodóvar, Los amantes pasajeros (Espanha: El Deseo, 2013).
} 
sucesso como atriz nem tampouco como cantora, transforma seu ódio pelo mundo em um novo talento, o de ser uma dominadora sexual. Nestas personagens de Almodóvar, não somente há uma mudança de direção do corpo que passa a encontrar novos caminhos, mas há também uma transformação do próprio corpo que, através da emoção, passa a ter qualidades outras com o intuito de traçar novas vias existenciais em um mundo que se transforma.

O corpo, através da emoção, acredita piamente que existe um outro mundo com novos objetos que passam a ter estatuto de verdadeiros. Sartre escreve que este processo da emoção diz respeito a um encantamento que é regido pela magia: “[...] Há uma estrutura existencial do mundo que é mágica. (...) a categoria "mágica" rege as relações interpsíquicas dos homens em sociedade e, mais precisamente, nossa percepção de outrem." 48 Esta magia faz com que a consciência mergulhe em determinada emoção, por inteiro, com o intuito de encontrar um novo caminho. Quando o mundo se apresenta como um lugar ameaçador no qual todas as rotas traçadas são impossíveis, a consciência se transforma, através da emoção, tornando-se uma nova consciência que passa a perceber um novo mundo com saídas possíveis. No entender de Sartre, a consciência emocionada "[...] precipita-se neste mundo por inteiro degradando-se; ela é nova consciência diante do mundo novo e é com o mais íntimo nela que o constitui, com essa presença a si mesma, sem distância, de seu ponto de vista sobre o mundo." 49 Desta forma pode-se compreender que as relações espaciais se modificam quando a pessoa está emocionada. Como a emoção faz com que a consciência perceba os objetos do mundo "sem distância", ela justamente perde a noção de perspectiva em relação ao mundo. É por esta razão que Sartre concebe que a consciência emocionada é uma consciência "degradada", justamente por perder a capacidade de se distanciar e perceber o objeto a partir de diversos ângulos. A característica que eu confiro a um objeto, através da minha consciência emocionada, é uma característica que define este objeto por inteiro e a partir de um ângulo achatado que o cristaliza nesta característica. Mas a consciência emocionada não tem consciência que ela está transformada e que, ao estar alterada, percebe o mundo sem distância. Ela acredita que os objetos do mundo realmente são da forma pela qual eles se apresentam, pois para Sartre "a emoção é um fenômeno de crença." ${ }^{50}$ A consciência sofre a emoção no sentido em que ela, através de um ato intencional irrefletido, transforma, de um só golpe, ela mesma e o mundo, alterando as relações espaciais e afetivas com os objetos e com as demais pessoas. Ao negar a distância entre ela e os objetos, a consciência emocionada passa a colar a qualidade ao objeto, sem possibilidade

\footnotetext{
48 Sartre, Esquisse, 58.

49 Sartre, Esquisse, 53.

50 Sartre, Esquisse, 53.
} 
de mudança de perspectiva: "[...] as qualidades que a emoção confere ao objeto e ao mundo, ela as confere ad aeternum. (....). A partir de agora o horrível está dentro da coisa, no coração da coisa, é sua textura afetiva, é constitutivo dela." 51 Uma pessoa que está deprimida por ter sido abandonada pelo seu grande amor, ao conferir a qualidade de horrível ao seu amor antigo, ela estende esta qualidade ao mundo. É como se ela enxergasse uma única imagem indissociável: uma pessoa horrível que está colada em um fundo de mundo horrível. Da mesma forma, uma pessoa que está apaixonada e esta paixão é correspondida, percebe a pessoa amada com um fundo de mundo maravilhoso, alegre e saltitante. É neste sentido que a pessoa emocionada vê o mundo sem distância entre o objeto e o mundo, como se não existisse a figura e o fundo, como se tudo fizesse parte de um mesmo quadro. Sartre escreve no Esquisse d'une théorie des émotions que "a consciência pode "ser-no-mundo" de duas maneiras diferentes." 52 A primeira forma de "serno-mundo" da consciência diz respeito à sua percepção de que os utensílios estão organizados no mundo em um complexo. A consciência percebe que para mudar algo do mundo é preciso somente realizar uma ação para modificar um elemento com o intuito de conseguir atingir determinado fim. A segunda forma de "ser-no-mundo" se torna presente quando a consciência percebe o mundo como uma totalidade fatal na qual não é possível modificar coisa alguma. É neste caso que surge a emoção, pois para Sartre

[...] há emoção quando o mundo dos utensílios desaparece bruscamente e o mundo mágico aparece em seu lugar (...). A emoção não é um acidente, é um modo de existência da consciência, uma das maneiras como ela compreende (...) seu "Ser-no-Mundo." 53

\section{O corpo e sua espacialidade}

Uma vez que a noção fenomenológica sartreana das emoções é uma forma de "Ser-no-Mundo" da consciência que diz respeito a uma modificação espacial do corpo em relação ao mundo, é preciso, neste ponto da discussão, voltar-se para a questão do corpo. O que o filósofo francês entende por corpo? No entender de Sartre "corpo" pode ser concebido por: "[...] Nascimento, passado, contingência, necessidade de um ponto de vista, condição de fazer toda ação possível sobre o mundo: tal é o corpo, tal qual ele é para

\footnotetext{
51 Sartre, Esquisse, 56.

52 Sartre, Esquisse, 61.

53 Sartre, Esquisse, 62.
} 
mim." ${ }^{54}$ Esta definição sartreana presente em L'être et le néant é fundamental para compreender que o corpo e o espaço no qual o corpo ocupa não podem ser pensados de forma isolada. O corpo tem uma determinada forma, pois se posiciona de determinado "ponto de vista" sobre este espaço. A partir deste ponto de vista, o corpo agirá em determinado espaço de uma forma singular específica, constituindo o seu próprio tamanho, pois segundo Sartre "[...] nosso corpo não é somente o que há muito tempo nomeamos de "a sede dos cinco sentidos"; ele é também o instrumento e a meta das nossas ações." ${ }^{55}$ Além de ser instrumento e meta de nossas ações, o corpo é "o centro da ação" 56 e "a forma contingente que toma a necessidade de minha contingência." 57 Pode-se depreender destas noções sartreanas que serão as minhas ações no mundo, em determinadas circunstâncias, que definirão o tamanho do meu corpo e o tamanho do meu mundo. No entender do filósofo Sartre "[...] O que é fundamental é minha relação com o mundo e esta relação define, simultaneamente, o mundo e o sentido, segundo o ponto de vista no qual a gente se localiza." ${ }^{\circ 8} \mathrm{O}$ poeta português Alberto Caeiro expressa de forma magnífica esta noção sartreana que diz respeito à constituição do ser humano a partir do horizonte que ele enxerga para si. Caeiro, a partir da vista da sua bela quinta no Ribatejo, com sua sabedoria que lhe é tão peculiar, escreve:

Da minha aldeia vejo quanto da terra se pode ver do Universo...

Por isso a minha aldeia é tão grande como outra terra qualquer,

Porque eu sou do tamanho do que vejo

E não do tamanho da minha altura... ${ }^{59}$

Os contornos do meu corpo, assim como o seu tamanho e o seu alcance, serão definidos em termos de espacialidade em relação aos objetos e às pessoas que se encontram ao meu redor. É o meu movimento em direção a um instrumento ou a uma pessoa, ou mais especificamente é o meu esforço em me aproximar ou me afastar deste ou desta que delimitará o meu corpo: "[...] É que meu corpo se expande sempre através da ferramenta que eu utilizo (...), porque ele é minha adaptação a estas ferramentas." 60 Além de ser a adaptação aos instrumentos, aos utensílios do mundo, meu corpo é definido pelas minhas ações e, desta forma, isto se faz sempre a posteriori, pois será

\footnotetext{
54 Sartre, L'être, 367.

55 Sartre, L'être, 359.

56 Sartre, L'être, 359.

57 Sartre, L'être, 348.

58 Sartre, L'être, 359.

59 Pessoa, Obra II, 43.

60 Sartre, L'être, 365.
} 
a ação que já aconteceu que definirá a dimensão do meu corpo. É por esta razão que Sartre concebe que "[...] o corpo é perpetuamente o ultrapassado. O corpo, (...) como centro de referência sensível, é este além do que eu sou. (...). A percepção (...) só pode ser feita no próprio lugar no qual o objeto é percebido e sem distância." 61 O filósofo francês concebe o corpo como "centro de referência sensível" porque será sempre a partir dele que se vivencia uma situação no mundo, mas apesar dele ser um centro de referência para o mundo, para mim ele se apresenta como um "oco" 62 . Para poder explicar este esboço em oco, ou essa presença de uma ausência, Sartre se refere a um homem que se encontra em um mirante no qual, para ele próprio, não há distância entre o seu corpo e o ponto de vista na qual ele se encontra, eles se fundem em um "corpo-ponto-de-vista"63. Assim como na emoção a consciência percebe os objetos do mundo sem perspectiva, ou seja, sem distância, o ser humano também percebe o seu próprio corpo sem distância: "[...] meu corpo (...) é, com efeito, o ponto de vista sobre o qual eu não posso tomar nenhum ponto de vista, o instrumento que eu não posso utilizar como meio de nenhum instrumento." 64

Por outro lado, o corpo não aparece no mundo de forma isolada, pois para Sartre "[...] é um fato objetivo que o corpo - que seja como organismo, como caráter ou como ferramenta - não me aparece jamais sem arredores (alentours), e deve ser determinado a partir de seus arredores." ${ }^{65}$ Como o corpo deve ser compreendido a partir de seus arredores, é preciso entender como são as relações espaciais deste corpo, isto é, a relação deste corpo com os demais corpos, ou seja, entender qual a significação do meu corpo para o outro e o que significa o corpo do outro para mim. No entender do filósofo francês, a aparição do corpo do outro para mim é puramente contingente, pois ele poderia estar em outro lugar e ser de outra forma. Além de ser contingente, "[...] o outro me é dado, originalmente, como corpo em situação." 66 Eu passo a significar o corpo do outro a partir dos gestos e das relações espaciais que o envolvem: o corpo de Mário ganha significação para mim a partir de sua ação de descer do Eléctrico 28, atravessar a rua, entrar em um café de Lisboa e pedir "uma bica". É claro que a dimensão espacial encontra-se indissociada da dimensão temporal, pois todos os gestos de Mário que se encontram reunidos em uma situação são percebidos no momento presente e significados a partir deste momento singular e único. O que Sartre

\footnotetext{
61 Sartre, L'être, 365.

62 Sartre, L'être, 362.

63 Sartre, L'être, 369.

64 Sartre, L'être, 380.

65 Sartre, L'être, 391.

66 Sartre, L'être, 384.
} 
ressalta é o fato de que estas dimensões espaciais e temporais apresentam-se como limites que, ao definir uma situação, definem a significação do corpo do outro. O que não pode deixar de ser dito é que esta significação nunca será completa, pois há uma dimensão da significação que não está dada, que será constituída somente no futuro. Esta dimensão não diz respeito a algo indecifrável sobre o outro, pois isto remeteria a algo que já está pronto e que se encontra oculto. Esta dimensão da significação diz respeito a um oco, um vazio, algo que ainda não está lá e que é nomeado por Sartre de "corpo-queindica-além-dele-mesmo" 67 . Mas será somente a partir do olhar do outro que eu me percebo como um vazio de corpo que indica que parte de mim está mais além, isto é, fora do meu alcance e do meu controle. Como está fora do meu alcance, meu corpo me escapa na direção da ultrapassagem da minha contingência na qual a significação da minha existência será dada apenas a partir do olhar do outro. No entender de Sartre "[...] Nós nos resignamos a nos ver pelos olhos do outro (...). É através dos conceitos do outro que eu conheço meu corpo. Mas segue-se que, na reflexão mesma, eu tomo o ponto de vista do outro sobre o meu corpo." 68 Desta forma, pode-se compreender que o meu corpo, desde sua constituição, sempre foi e sempre será mediado pelo olhar do outro. Será somente após o olhar do outro que eu percebo o meu corpo e que, somente a partir de então, dou-lhe uma significação. Este olhar do outro instaura, de uma só vez, uma espacialidade e uma temporalidade ao meu ser na qual eu estarei ad eternum fora do meu alcance, assim como as uvas maduras da fábula de Esopo. Este estar fora do meu alcance significa que só posso perceber a mim mesmo a partir do que o outro diz sobre mim; deste ponto de vista pode-se suspeitar que eu seja um olhar estrangeiro imerso na linguagem. Neste momento da discussão torna-se relevante perguntar como se dá esta relação na qual o outro, aquele que jamais poderei tomar como objeto, me diz quem eu sou.

\section{A espacialidade das relações intersubjetivas}

É com o intuito de compreender as relações intersubjetivas que Sartre nos apresenta algumas formas pelas quais eu posso me relacionar com o outro. Para Sartre há, em princípio, duas formas de lidar com este olhar do outro: "[...] Transcender a transcendência do outro ou, ao contrário, engolir em mim esta transcendência sem retirar-lhe sua característica de transcendência, estas são as duas atitudes primitivas que eu tomo face à face com o outro." 69

\footnotetext{
${ }^{67}$ Sartre, L'être, 391.

68 Sartre, L'être, 394-396.

69 Sartre, L'être, 403.
} 
Esta passagem do L'être et le néant pode ser compreendida a partir do amor, que é uma das formas de se relacionar com o outro que Sartre coloca em cena neste livro. Amar o outro não significa querer transformá-lo em meu objeto, pelo contrário, sou eu que me torno objeto do outro por amar no outro aquilo que me escapa, isto é, a sua liberdade. Para Sartre

Seduzir, é assumir inteiramente e como um risco a correr minha objetividade para o outro, é me colocar sob o seu olhar e me fazer ser visto por ele, é correr o risco de ser-visto para fazer um novo ponto de partida e de me apropriar do outro na e pela minha objetividade. ${ }^{70}$

É a partir da existência do outro e de seu olhar que eu constituo emoções ou atitudes frente ao outro. O desejo é uma forma de lidar com o olhar do outro que afirma a existência do corpo do outro e a própria existência do meu corpo de um só golpe: "[...] o desejo não é somente desvelamento do corpo do outro, mas a revelação do meu próprio corpo." $71 \mathrm{O}$ meu desejo abarca não somente o corpo do outro, mas também a situação na qual o corpo age, ou seja, suas atitudes e seus gestos frente ao mundo: "[...] o desejo me compromete; eu sou cúmplice do meu desejo." $72 \mathrm{O}$ desejo é um ato de crença na qual o outro se torna um ser encantado; é um ato de afirmação de uma relação que possui uma significação singular que não se encerra nela mesma. Existe um transbordamento do sentido da atitude desejante por não se saber previamente o que advirá desta relação de descoberta e de mergulho no outro. A partir desta relação transcendente, Sartre apresenta uma noção muito relevante que é a nous-sujet: “[...] No "nós"-sujeito, nenhuma pessoa é objeto. O nós envolve uma pluralidade de subjetividades que se reconhecem umas às outras como subjetividades." 73 Sartre escreve que se pode entender este nós-sujeito a partir da experiência do teatro, pois o espectador, no momento da encenação, ao envolver sua consciência imaginante na peça, ele se irrealiza de forma coletiva. O nós-sujeito nesta situação é vivenciado pela plateia enquanto um todo, pois ao imaginar coletivamente as personagens, suas venturas e desventuras, ao amar e sofrer junto com delas há o "[...] surgimento da consciência do espetáculo, se constitui não-teticamente como consciência (de) ser co-espectador do espetáculo."74 Para o filósofo francês, a vivência de ser plateia de um espetáculo teatral é a experiência por excelência do nós-sujeito, pois há um encantamento que transporta as consciências de forma coletiva para um mundo imaginário, transformando as consciências

\footnotetext{
70 Sartre, L'être, 412.

71 Sartre, L'être, 429.

72 Sartre, L'être, 428.

73 Sartre, L'être, 453.

74 Sartre, L'être, 454.
} 
realizantes em consciências imaginantes. A plateia enquanto um todo se torna imaginária e mergulha neste universo imaginário durante as duas ou mais horas de duração da peça de teatro.

Apesar de explicar esta forma de relação, o nós-sujeito, na qual todos os envolvidos tornam-se sujeitos e vivenciam de forma coletiva as experiências, Sartre dirá que esta situação é uma abstração e que, na realidade cotidiana, ela não existe. O nós-sujeito é um sentimento psicológico de "pertencimento a uma comunidade-sujeito" 75 que pode ser vivenciada em um partido político, por exemplo, mas que não define as relações concretas entre as pessoas. É preciso sempre ter em mente o fato de que, para o filósofo francês, o conflito é, por excelência, forma pela qual eu me relaciono com o outro: "[...] É, então, em vão que a realidade-humana procura sair deste dilema: transcender o outro ou se deixar transcender por ele. A essência das relações entre consciências (...) é o conflito." 76 Segundo o filósofo português André Barata, a posição sartreana na qual toda a relação está fadada ao fracasso (échec) é um tanto fatalista:

[...] O pensamento de Sartre só nos permite encarar a relação intersubjectiva fazendo-a assentar no perigo para mim que o outro constitui, na ameaça que ele representa ao meu ser e à minha autonomia, posição conflitual suscitada pela perda de domínio sobre o sentido das "minhas" possibilidades. ${ }^{77}$

No entender do filósofo português é possível pensar em uma saída para o conflito sem solução apresentado por Sartre. Para André Barata a intersubjetividade é uma relação espacial de descoberta do outro. Ir ao encontro da alteridade significa constituir um campo de força afetivo no qual o outro é a possibilidade do conflito; o outro é tudo o que me causa crise, o que altera minha relação. $\mathrm{O}$ conflito pode ser entendido como positivo, pois a crise inaugura uma nova situação: um momento de escolha.

Desta forma pode-se concluir que a intersubjetividade é constituída a partir deste espaço de luta entre duas liberdades que querem se afirmar no mesmo lugar e no mesmo espaço de tempo. No livro Fantasmas de la vida moderna, Ampliaciones y quiebras del sujeto en la ciudad contemporánea, o filósofo espanhol Luis Arenas escreve um belíssimo epílogo intitulado $A$ cubierto: Elogio del espacio frágil. Arenas, ao propor a análise da arquitetura a partir da filosofia, aponta que este espaço no qual a intersubjetividade se constitui é um espaço delicado que precisa nos abrigar com cuidado: "Um

75 Sartre, L'être, 464.

76 Sartre, L'être, 470.

77 André Barata, "O Outro e a relação. O contributo das fenomenologias da intersubjectividade", Phainomenon, Revista de Fenomenologia 16-17 (Primavera e Outono de 2008), 308 . 
espaço frágil será fluido, flexível, amável. Como os fluidos, adotará a forma do que o contém. Escutará atento e em silêncio as necessidades de seu entorno e de seus usuários; se adaptará a ele como uma segunda pele." ${ }^{\prime 78}$ Deste confronto neste espacio frágil advirão seres humanos em projeto que serão do tamanho do alcance do seu olhar, engajados em relações intersubjetivas em crise, contudo possíveis, em um mundo brutalizado a transformar.

\section{BIBLIOGRAFIA FINAL}

Adloff, Jean Gabriel. Sartre. Index du Corpus philosophique. I - L'Être et le Néant. Critique de la Raison Dialectique. Paris:Librairie des Méridiens, Klincksieck et Cie, 1981.

Arenas, Luis. Fantasmas de la vida moderna. Ampliaciones y quiebras del sujeto en la ciudad contemporánea. Madrid: Colección Estructuras y Procesos. Serie Filosofía. Editorial Trotta, 2011.

André Barata, "O outro e a relação. O contributo das fenomenologias da intersubjectividade", Phainomenon, Revista de Fenomenologia 16-17 (Primavera e Outono de 2008), 295-314.

. "Vida temporal comum: o caráter temporal da intersubjetividade afetiva", in Tempo e Subjetividades, perspectivas plurais orgs. Ariane P.Ewald, Jorge Coelho Soares, Maria de Fátima V. Severiano, Cássio Braz de Aquino, (Rio de Janeiro: 7 Letras: Pequeno Gesto, 2013), 117-153.

Esopo. Fábulas. Tradução de Antônio Carlos Vianna. Porto Alegre: L\&PM, 1999.

Ewald, Ariane P.; Soares, Jorge C.; Severiano, Maria de Fátima V.; Aquino, Cássio B. (coords.) Tempo e Subjetividades, perspectivas plurais. Rio de Janeiro: 7 Letras: Pequeno Gesto, 2013.

Pessoa, Fernando. Obra poética II. Poemas de Alberto Caeiro. Porto Alegre, RS: L\&PM, 2012.

Pirandello, Luigi. Vestir os nus. Tradução de Millôr Fernandes. Rio de Janeiro: Civilização Brasileira, 2007.

. Seis Personagens à Procura de Autor. Para Cada Um Sua Verdade. Esta Noite Improvisa-se. Traduções de Mário Feliciano e Fernando José Oliveira, Natércia Freire e Maria da Graça Freire, Luís Miguel Cintra e Osório Mateus. Traduções revistas por José Maria Vieira Mendes e Jorge Silva Melo. Lisboa: Artistas Unidos/ Livros Cotovia, 2009.

Sartre, Jean-Paul. Esquisse d'une théorie des émotions. Paris: Hermann, 1960.

. L'être et le néant. Essai d'ontologie phénoménologique. Edition corrigée avec index par Arlette Elkaïm-Sartre. Paris: Gallimard, 2007.

${ }^{78}$ Luis Arenas, Fantasmas de la vida moderna. Ampliaciones y quiebras del sujeto en la ciudad contemporânea, (Madrid: Editorial Trota, 2011), 216. 


\section{REFERÊNCIAS FILMOGRÁFICAS}

Todo sobre mi madre (Tudo sobre minha mãe). Direção: Pedro Almodóvar. Elenco: Cecilia Roth, Marisa Paredes, Penélope Cruz, Antonia San Juan., Rosa María Sardá. España/ França: El Deseo, 1999, película (105 min), son., color., legendado.

Los amantes pasajeros (Os amantes passageiros). Direção: Pedro Almodóvar. Elenco: Javier Cámara, Cecilia Roth, Carlos Areces, Raúl Arévalo, Lola Dueñas. España: El Deseo, 2013, película (91 min), son., color., legendado. 
(Página deixada propositadamente em branco.) 